Supporting Information for

\title{
Cesium Cation Complexation by a Flavin Receptor via Self-Assembly and Deprotonation
}

\author{
Yoshimi Oka*
}

Research Promotion Institute, Oita University, 700 Dannoharu, Oita 870-1192, Japan 


\section{Contents}

1. Synthesis

2. Crystal structure

3. Absorption and fluorescence spectra

4. ESI mass spectrum

5. UV-vis titrations

6. ${ }^{1} \mathrm{H}$ NMR titrations

7. Determination of stability constants

8. Fluorescence titrations

9. References 


\section{Synthesis}

All chemicals and solvents were purchased from Aldrich, TCI, Wako or Nacalai, and used as received without further purification.

Scheme S1. A synthetic route to FlH-MB.

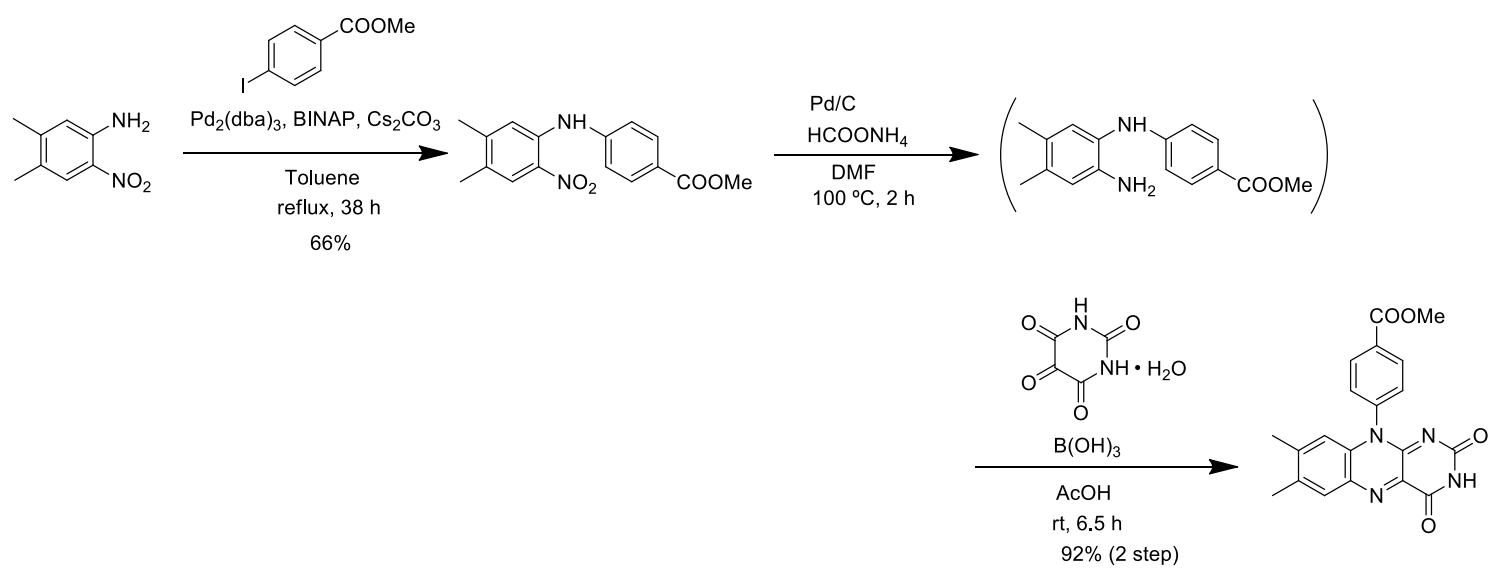

\section{4-((4,5-Dimethyl-2-nitrophenyl)amino)benzoic acid methyl ester.}

A mixture of 4,5-dimethyl-2-nitroaniline $(4.5 \mathrm{~g}, 27 \mathrm{mmol})$ and 4-iodobenzoic acid methyl ester $(7.1 \mathrm{~g}, 27 \mathrm{mmol})$ in anhydrous toluene $(80 \mathrm{~mL})$ was stirred under nitrogen atmosphere at room temperature. After adding $\mathrm{Pd}_{2}(\mathrm{dba})_{3}$ (tris(dibenzylideneacetone)dipalladium(0), $1.3 \mathrm{~g}, 1.4 \mathrm{mmol}$ ), ( \pm )-BINAP (2,2'-bis(diphenylphosphino)-1,1'-binaphthyl, $1.3 \mathrm{~g}, 2.1 \mathrm{mmol})$ and $\mathrm{Cs}_{2} \mathrm{CO}_{3}(12.5 \mathrm{~g}$, $38 \mathrm{mmol}$ ), the resulting suspension was heated to reflux and maintained for $38 \mathrm{~h}$. Then the reaction solution was cooled to room temperature and filtered through Celite, and the Celite was rinsed with EtOAc. Subsequently, the organic phase was washed with water and brine, dried with $\mathrm{MgSO}_{4}$, and evaporated in vacuo. 4-((4,5-dimethyl-2-nitrophenyl)amino)benzoic acid methyl ester was purified by chromatography on silica gel with $\mathrm{CH}_{2} \mathrm{Cl}_{2}$ and recrystallization with $\mathrm{MeOH}$, and obtained as a brown crystal (5.4 g, 18 mmol, 66\%yield). ${ }^{1} \mathrm{H}$ NMR (500 MHz, acetone- $\left.\mathrm{d}_{6}, 29{ }^{\circ} \mathrm{C}\right): \delta=9.27(\mathrm{~s}, 1 \mathrm{H}), 7.99(\mathrm{dd}, J=8.8,1.9 \mathrm{~Hz}, 2 \mathrm{H}), 7.95(\mathrm{~s}, 1 \mathrm{H}), 7.43(\mathrm{dd}, J=$ 8.8, $1.9 \mathrm{~Hz}, 2 \mathrm{H}), 7.40$ (s, 1H), 3.87 (s, 3H), 2.30 (s, 3H), $2.29 \mathrm{ppm}(\mathrm{s}, 3 \mathrm{H}) ;{ }^{13} \mathrm{C}$ NMR (125.7 MHz, acetone- $\left.\mathrm{d}_{6}, 22{ }^{\circ} \mathrm{C}\right): \delta=179.2,165.8,146.4,145.0,137.8,130.9,129.3,126.0,124.5$, $120.0,118.8,51.2,19.3,17.8 \mathrm{ppm}$. 

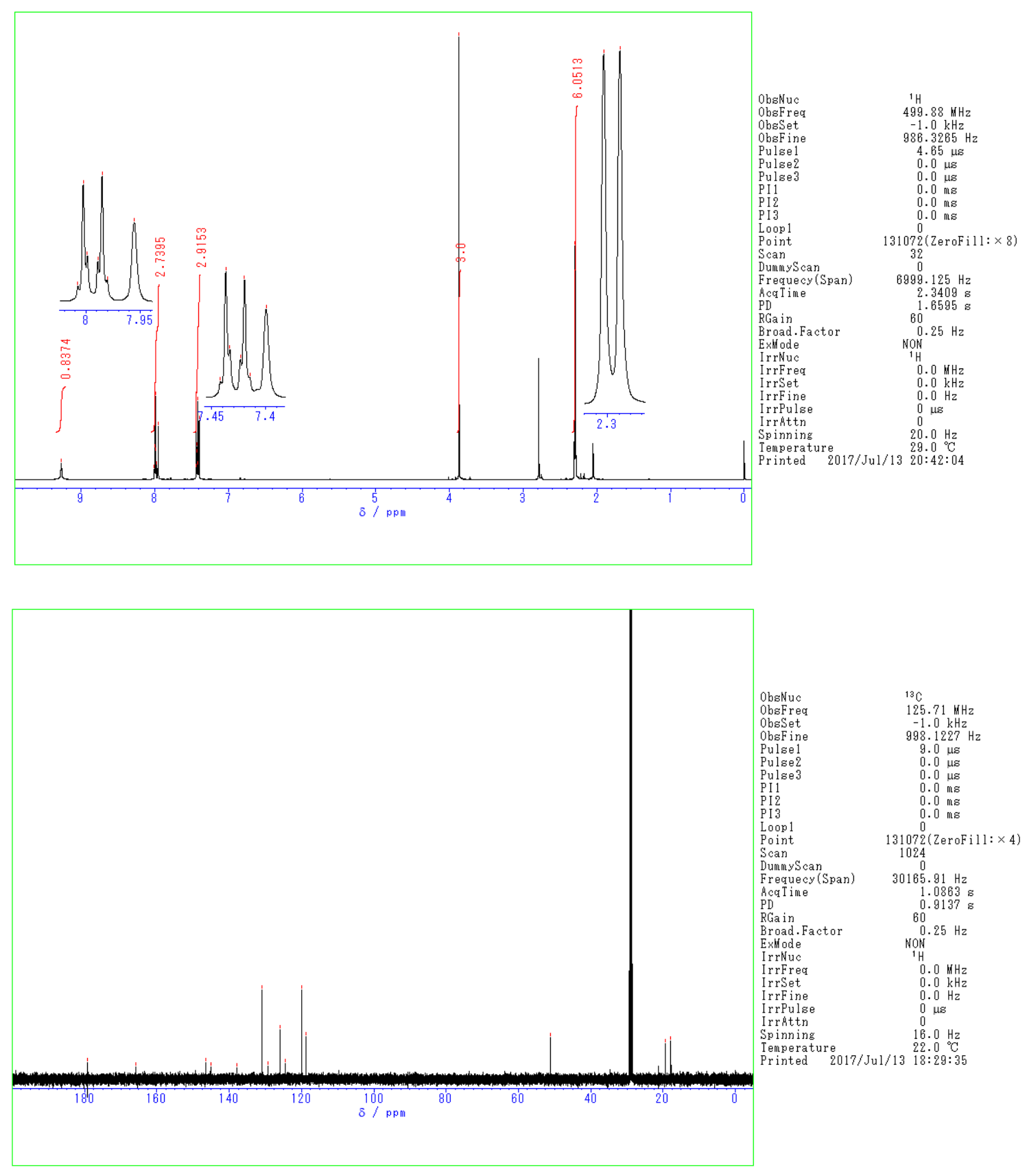

Figure S1. ${ }^{1} \mathrm{H}$ and ${ }^{13} \mathrm{C}$ NMR spectra for 4-((4,5-Dimethyl-2-nitrophenyl)amino)benzoic acid methyl ester. 


\section{4-(7',8'-Dimethylisoalloxazin-10'-yl)benzoic acid methyl ester.}

To 4-((4,5-dimethyl-2-nitrophenyl)amino)benzoic acid methyl ester $(1.7 \mathrm{~g}, 5.7 \mathrm{mmol})$ in anhydrous DMF $(50 \mathrm{~mL}), \mathrm{HCOONH}_{4}(1.9 \mathrm{~g}, 30 \mathrm{mmol})$ and $10 \% \mathrm{Pd} / \mathrm{C}(0.5 \mathrm{~g}, 0.47 \mathrm{mmol})$ were added, and the suspension was stirred under nitrogen atmosphere at room temperature. Then the reaction was heated to $100{ }^{\circ} \mathrm{C}$ and maintained for $2 \mathrm{~h}$, when the starting material was consumed as determined by TLC. After cooling to room temperature, the reaction solution was filtered through Celite using $\mathrm{CH}_{2} \mathrm{Cl}_{2}$. The organic phase was washed with water, dried with $\mathrm{MgSO}_{4}$, and evaporated in vacuo. The reduction product of brown solution including small amount of DMF was used for the following reaction without further purification. To the reduction product dissolved in $\mathrm{AcOH}(40 \mathrm{~mL}), \mathrm{B}(\mathrm{OH})_{3}(7.2 \mathrm{~g}, 116 \mathrm{mmol})$ and alloxan monohydrate $(3.7 \mathrm{~g}, 23$ mmol) were added, and then the reaction mixture was stirred at room temperature for $6.5 \mathrm{~h}$. The reaction proceeded with precipitation of powder. The powder was filtered, collected, washed with water and dried in vacuo. 4-(7',8'-dimethylisoalloxazin-10'-yl)benzoic acid methyl ester was obtained as a yellow powder (2.0 g, $5.3 \mathrm{mmol}, 93 \%$ yield). ${ }^{1} \mathrm{H}$ NMR (500 MHz, DMSO-d 6 , $\left.29^{\circ} \mathrm{C}\right): \delta=11.33(\mathrm{~s}, 1 \mathrm{H}), 8.28(\mathrm{~d}, J=8.5,2 \mathrm{H}), 7.98(\mathrm{~s}, 1 \mathrm{H}), 7.59(\mathrm{~d}, J=8.5,2 \mathrm{H}), 6.56(\mathrm{~s}, 1 \mathrm{H})$, $3.95(\mathrm{~s}, 3 \mathrm{H}), 2.38(\mathrm{~s}, 3 \mathrm{H}), 2.28 \mathrm{ppm}(\mathrm{s}, 3 \mathrm{H}) ;{ }^{13} \mathrm{C}$ NMR (125.7 MHz, DMSO-d $\left.6,22{ }^{\circ} \mathrm{C}\right): \delta=$ 179.1, 165.5, 159.6, 155.3, 151.3, 146.2, 140.1, 138.0, 135.8, 133.5, 131.8, 131.1, 130.8, 130.7, $128.5,52.4,20.3,18.7$. 

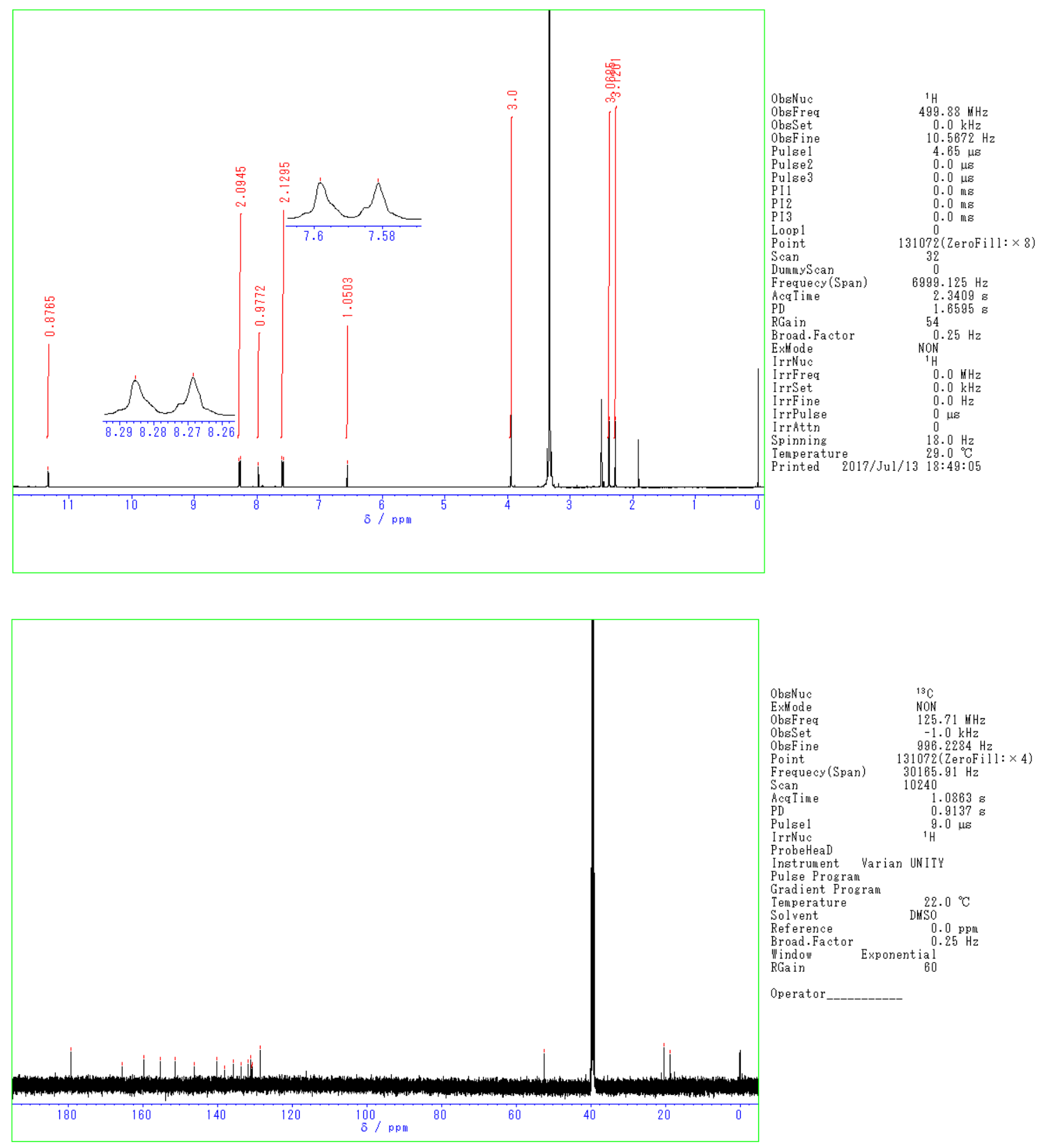

Figure S2. ${ }^{1} \mathrm{H}$ and ${ }^{13} \mathrm{C}$ NMR spectra for $4-\left(7^{\prime}, 8^{\prime}\right.$-Dimethylisoalloxazin-10'-yl)benzoic acid methyl ester. 


\section{Crystal structure}

A single crystal was mounted in a loop, and diffraction data were collected at $173 \mathrm{~K}$ on a Rigaku R-AXIS RAPID diffractometer using filtered $\mathrm{Cu}-\mathrm{K} \alpha$ radiation with $\omega$ scan mode. The data were corrected for Lorentz and polarization effects. The structure was solved by direct methods ${ }^{1}$ and expanded using Fourier techniques. The non-hydrogen atoms were refined anisotropically. Hydrogen atoms were refined using the riding model. The final cycle of full-matrix least-squares refinement was based on number of observed reflections $(I>2 \sigma(\mathrm{I}))$ and $n$ variable parameters and converged (large parameter shift was $\sigma$ times its esd) with unweighted agreement factors of $\mathrm{R} 1=\Sigma\|\mathrm{Fo}|-| \mathrm{Fc}\| / \Sigma|\mathrm{Fo}|, \mathrm{wR} 2=\left[\Sigma\left(\mathrm{w}\left(\mathrm{Fo}^{2}-\mathrm{Fc}^{2}\right)^{2}\right) / \Sigma \mathrm{w}\left(\mathrm{Fo}^{2}\right)^{2}\right]^{1 / 2}$. No extinction corrections have been applied (Table S1). Neutral atom scattering factors and values used to calculate the linear absorption coefficient are from the literature. ${ }^{2}$ All calculations were performed using the CrystalStructure crystallographic software package ${ }^{3}$ except for refinement, which was performed using SHELXL-97. ${ }^{1}$ The supplementary crystallographic data for this paper can be found in the Supporting Information and has been deposited at the Cambridge Crystallography Data Base with the identification number CCDC 1563747. 
Table S1. Summary of Crystallographic Data of FlH-MB.

Empirical formula

Formula weight

Crystal system

Space group

Lattice parameters

$Z$ value

Temperature

Crystal color, habit

Crystal dimensions

$D_{\text {calc }}$

$F_{000}$

$\mu$

Empirical Correction

Wavelength

Radiation

$\theta$ Range for Data Collection

Reflections collected

Independent reflections

Threshold

No. parameters

No. restraints

$R 1$

$R 1$ (all)

$\mathrm{w} R 2$ (all)

GOF on $F^{2}$

Diff density, max, min
$\mathrm{C}_{20} \mathrm{H}_{16} \mathrm{~N}_{4} \mathrm{O}_{4}$

376.37

triclinic

$P 1$ (No. 2)

$a=7.9811(3) \AA, b=10.8039(4) \AA, c=11.8435(4) \AA$

$\alpha=68.289(2), \beta=81.002(2), \gamma=65.825(2)^{\circ}$

$V=865.56(5) \AA^{3}$

2

173(1) K

yellow, platelet

$0.290 \times 0.060 \times 0.030 \mathrm{~mm}$

$1.444 \mathrm{~g} / \mathrm{cm}^{3}$

392.00

$8.604 \mathrm{~cm}^{-1}$

$T_{\min }=0.811, T_{\max }=0.975$

$1.54187 \AA$

$\mathrm{Cu} \mathrm{K} \alpha$

$4.02-68.23^{\circ}$

9971

3105

$I>2 \sigma(\mathrm{I})$

256

0

0.0471

0.0652

0.1325

0.981

$0.320,-0.210$ 


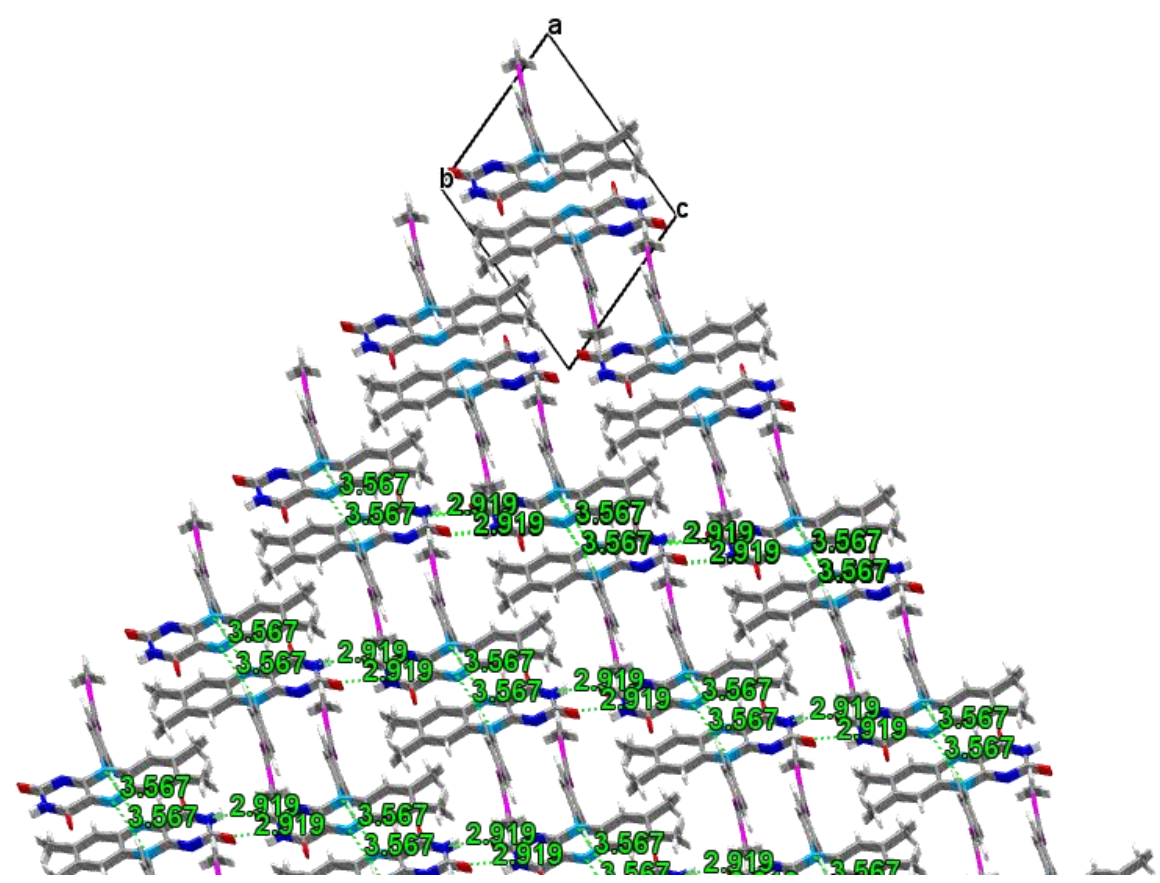

Figure S3. 3D network of FlH-MB crystal structure. The nearest neighbor distances (in $\AA$ ) between the isoalloxazine rings through $\pi-\pi$ stacking and hydrogen bonding are shown.

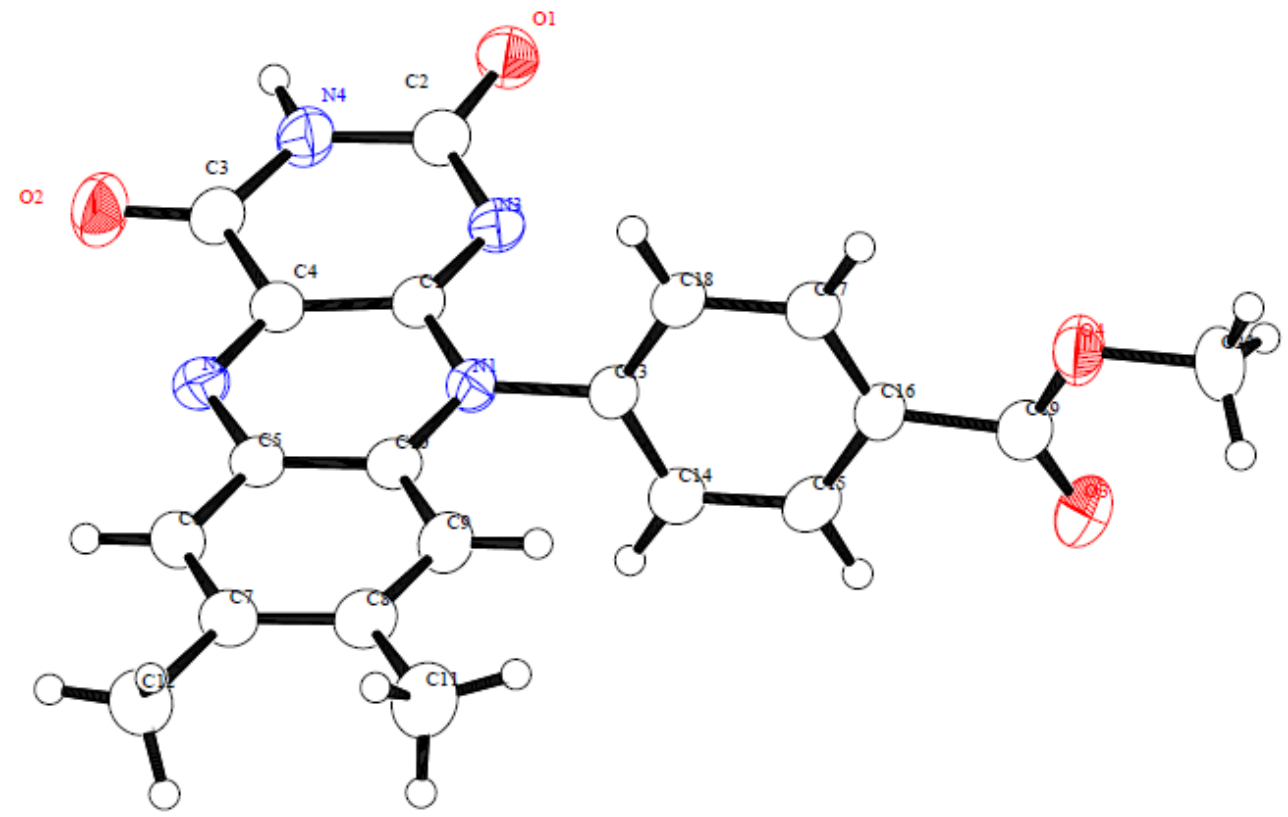

Figure S4. Thermal ellipsoidal model of Fl-MB crystal structure. The ellipsoids are drawn at $50 \%$ probability level with isotropic hydrogen atoms are represented by spheres of arbitrary size. The atom numbers are used in Table $\mathrm{S} 2$. 
Table S2. Distances from the least-squares plane of FlH ring. The plane is expressed as $1.0051 \mathrm{x}$ $-0.9228 y-z+5.8181=0$.

\begin{tabular}{|c|c|c|}
\hline atom & distances from the plane $(\AA)$ & reference data of 10 -methylisoalloxazine $(\AA)$ \\
\hline N1 & & in ref. 4 \\
C1 & -0.07770 & 0.025 \\
N3 & -0.04125 & 0.016 \\
C2 & -0.01441 & 0.024 \\
N4 & 0.08962 & -0.009 \\
C3 & 0.08647 & -0.052 \\
C4 & 0.001925 & -0.044 \\
N2 & -0.04398 & 0.015 \\
C5 & -0.07407 & 0.042 \\
C6 & -0.04551 & 0.049 \\
C7 & 0.002784 & 0.025 \\
C8 & 0.05505 & -0.030 \\
C9 & 0.07211 & -0.056 \\
C10 & 0.02994 & -0.025 \\
\hline av. & -0.03925 & 0.019 \\
\hline
\end{tabular}




\section{Absorption and fluorescence spectra}

Absorption and fluorescence spectra were recorded on a Shimadzu UV-2600 UV-vis spectrophotometer and a HORIBA SPEX Fluorolog3-21 spectrofluorometer, respectively. The experiments were performed at $25^{\circ} \mathrm{C}$ (with a temperature controlled unit) for UV-vis and at 20 ${ }^{\circ} \mathrm{C}$ (ambient temperature) for fluorescence using fresh samples. For all fluorescence spectroscopy analysis, the corrected data were used. For evaluation of fluorescence quantum yield, the solution of sample or standard (in a fluorescence cell with a SEPTA screw cap) was treated with Ar bubbling before use. The relative quantum yield of sample was related to that of a solution of a standard by the equation

$$
\Phi_{F(\text { sample })}=\left(\frac{\mathrm{A}_{\text {standard }}}{\mathrm{A}_{\text {sample }}}\right)\left(\frac{\mathrm{F}_{\text {sample }}}{\mathrm{F}_{\text {standard }}}\right)\left(\frac{\mathrm{n}_{\text {sample }}}{\mathrm{n}_{\text {standard }}}\right)^{2} \Phi_{F \text { (standard })}
$$

$\Phi_{\mathrm{F}}$ is the fluorescence quantum yield, $\mathrm{A}$ is the absorbance, $\mathrm{F}$ is the area under the corrected emission curve and $\mathrm{n}$ is the refractive index. ${ }^{5}$ Here, $\Phi_{\mathrm{F}(\mathrm{sample})}$ of each solution was estimated using riboflavin as a standard material. ${ }^{6}$

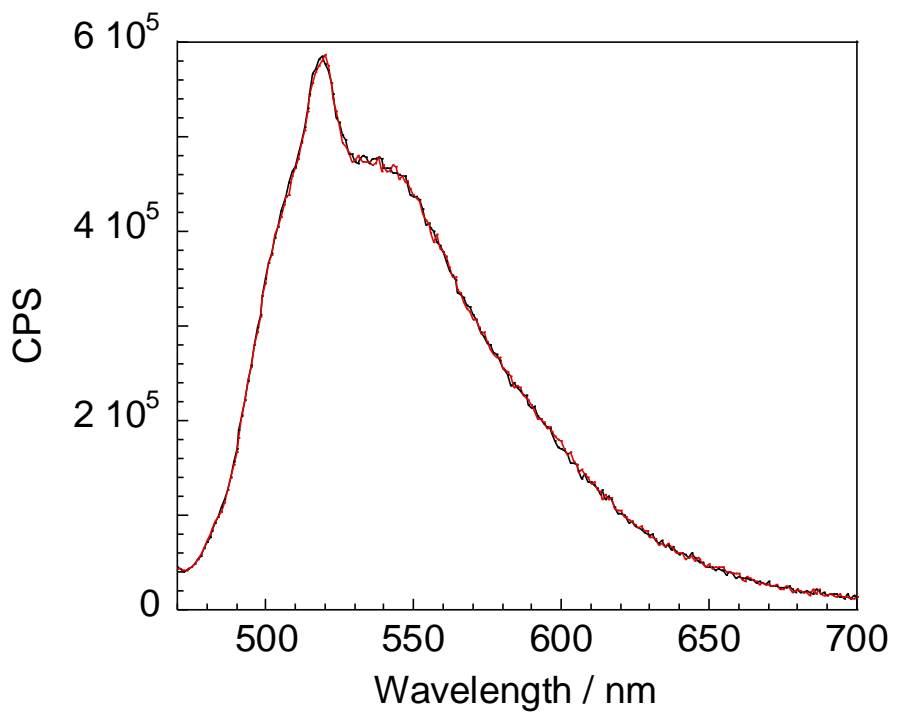

Figure S5. Fluorescence spectra of FlH-MB (0.1 $\mu \mathrm{M}$, DMSO solution). Excitation $450 \mathrm{~nm}$. 
Table S3. Fluorescence quantum yields of FlH-MB.

\begin{tabular}{|l|c|c|c|c|c|}
\hline & $\mathrm{A}$ & $\mathrm{F}$ & $\mathrm{n}$ & $\mathrm{Q}_{\mathrm{F}(\text { standard })}$ & $\mathrm{Q}_{\mathrm{F}(\text { sample })}$ \\
\hline $0.1 \mu \mathrm{M}$ riboflavin/DMSO & 0.00076 & 96480000 & 1.483 & 0.1 & \\
\hline $0.1 \mu \mathrm{M}$ FlH-MB/DMSO & 0.00112 & 44490000 & 1.483 & & 0.031 \\
\hline $0.1 \mu \mathrm{M}$ riboflavin/AcCN & 0.00109 & 156700000 & 1.341 & 0.3 & \\
\hline $0.1 \mu \mathrm{M}$ FlH-MB/AcCN & 0.00114 & 376400000 & 1.341 & & 0.69 \\
\hline
\end{tabular}




\section{ESI mass spectrum}

The electrospray ionization (ESI) mass spectra were obtained on a JEOL JMS-T100CS. $0.5 \mathrm{mM}$ FlH-MB solution (DMSO:MeOH = 1:1) was injected into the system, where $\mathrm{Cs}^{+}$ion existed.

a)

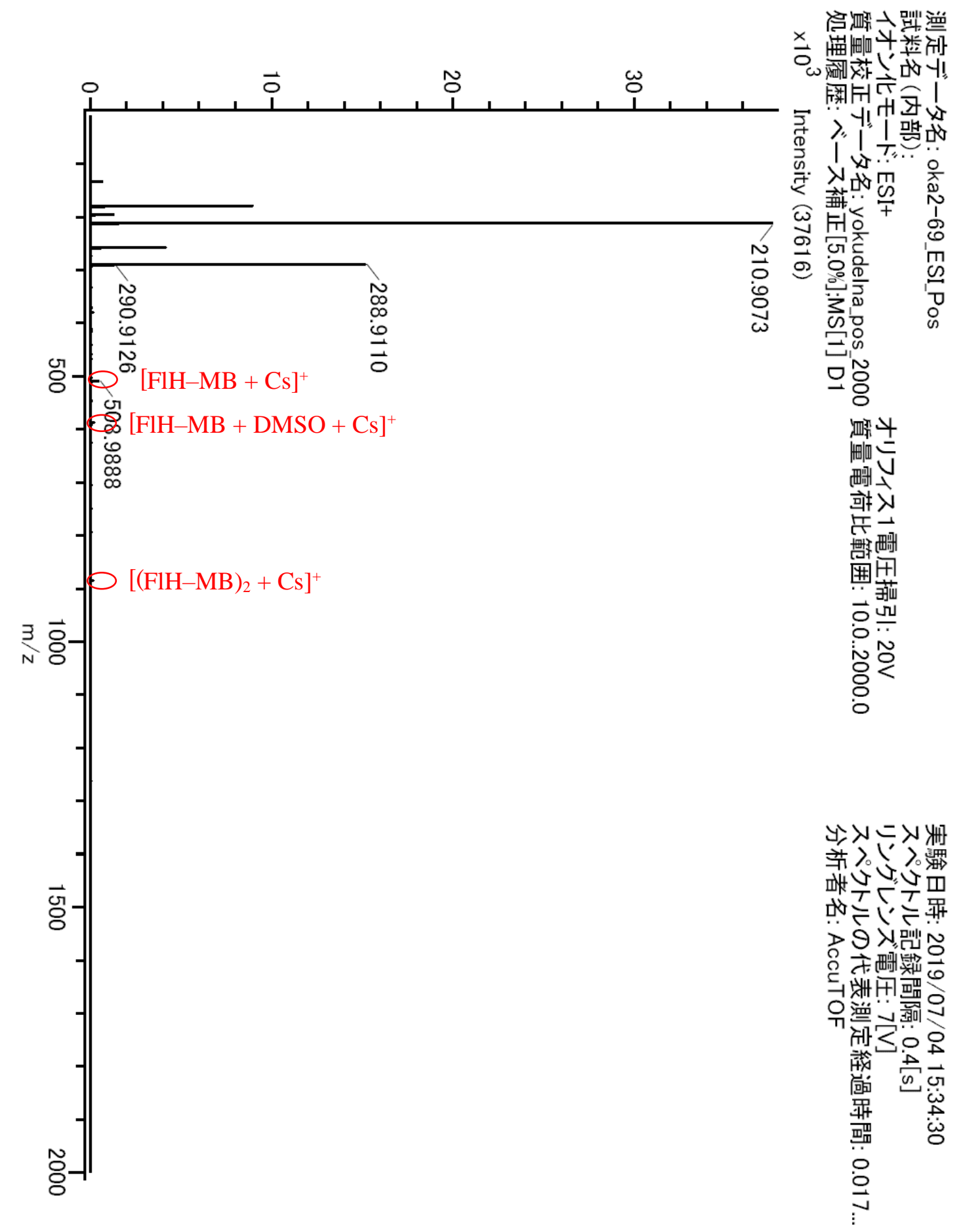


b)

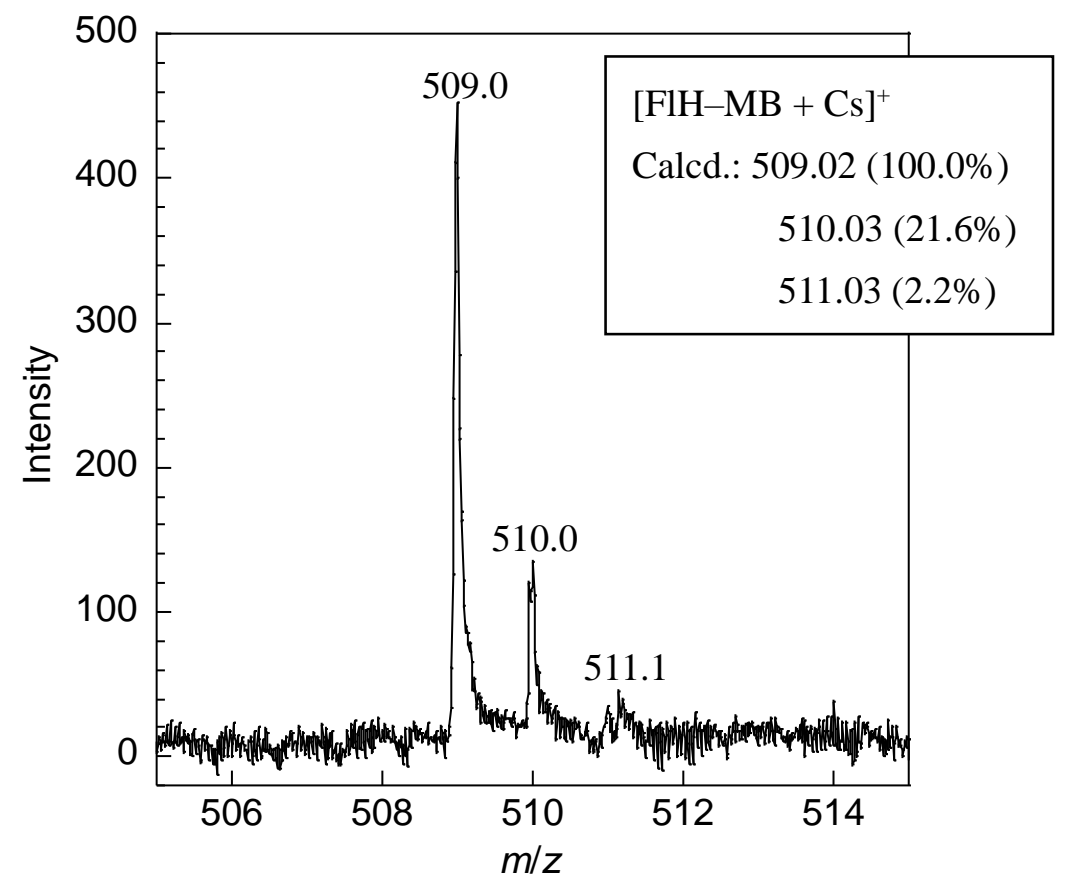

c)

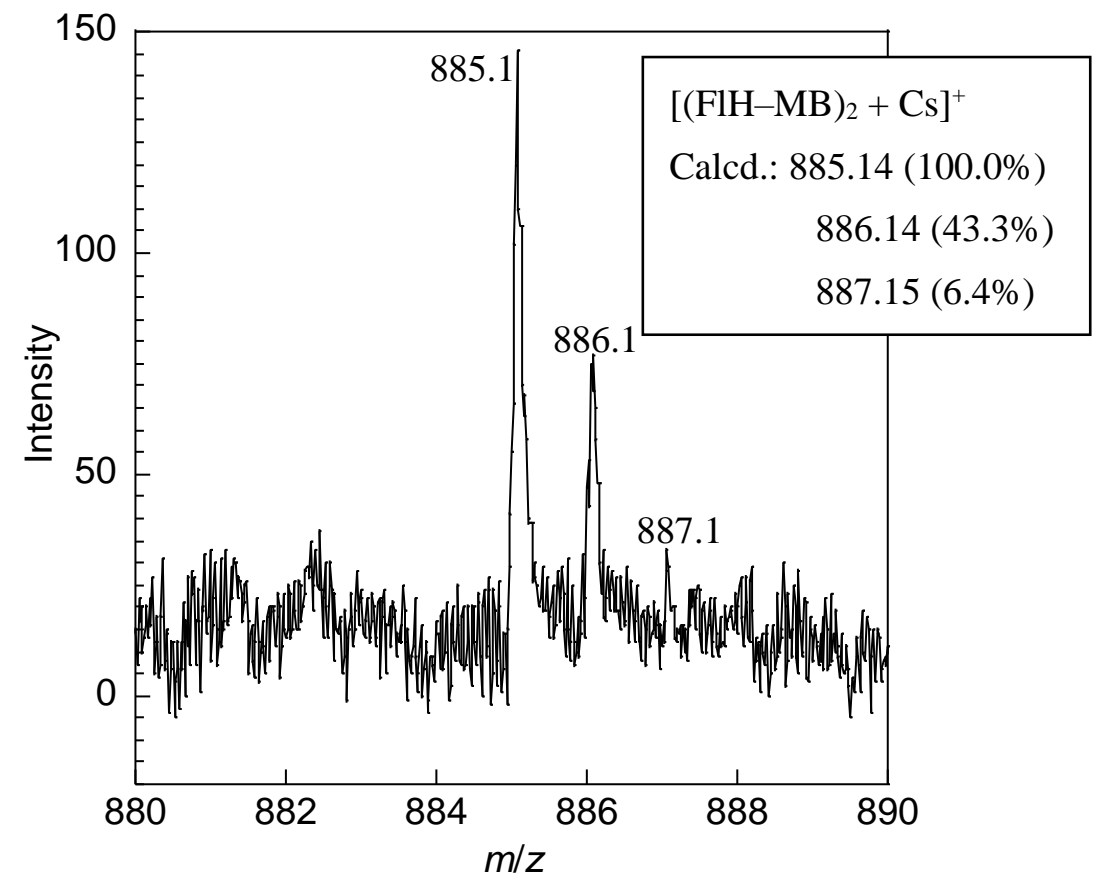

Figure S6. ESI-MS spectrum of FlH-MB in the presence of $\mathrm{Cs}^{+}$ion (a), and the detailed peak structures corresponding to $[\mathrm{FlH}-\mathrm{MB}+\mathrm{Cs}]^{+}(\mathrm{b})$ and $\left[(\mathrm{FlH}-\mathrm{MB})_{2}+\mathrm{Cs}\right]^{+}$(c) with the lists of predicted isotope distribution. 


\section{UV-vis titrations}

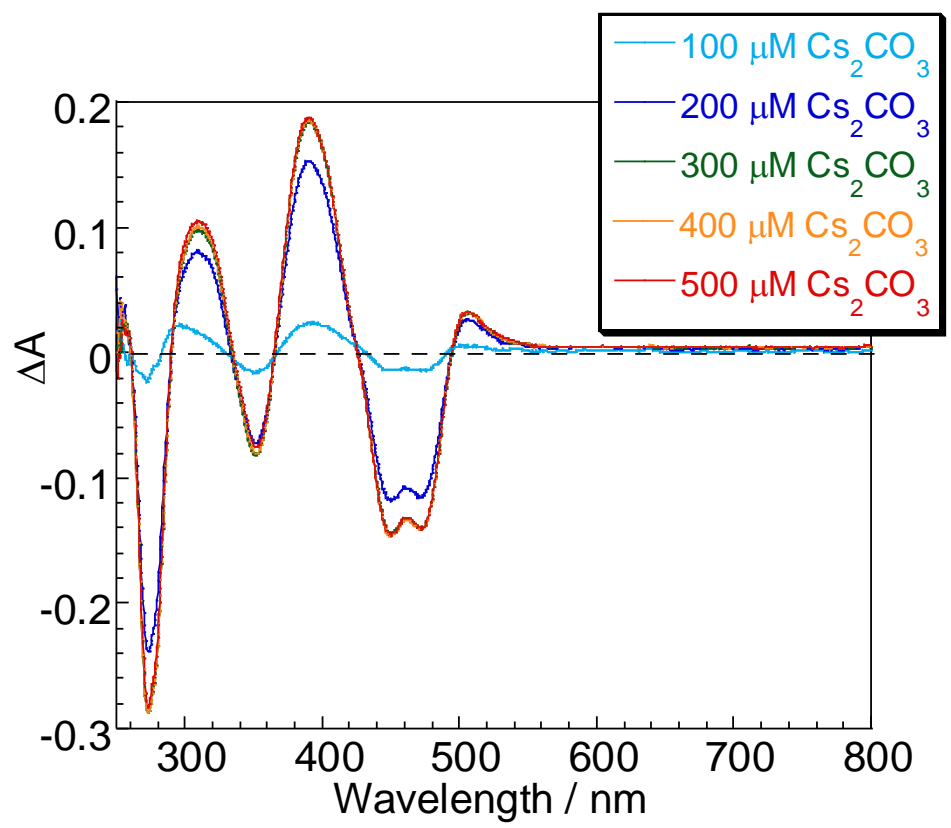

Figure S7. Differential absorption spectra of FlH-MB (50 $\mu \mathrm{M}$, DMSO solution) titrated with $\mathrm{Cs}_{2} \mathrm{CO}_{3}$ aq., corresponding to Figure 2 .

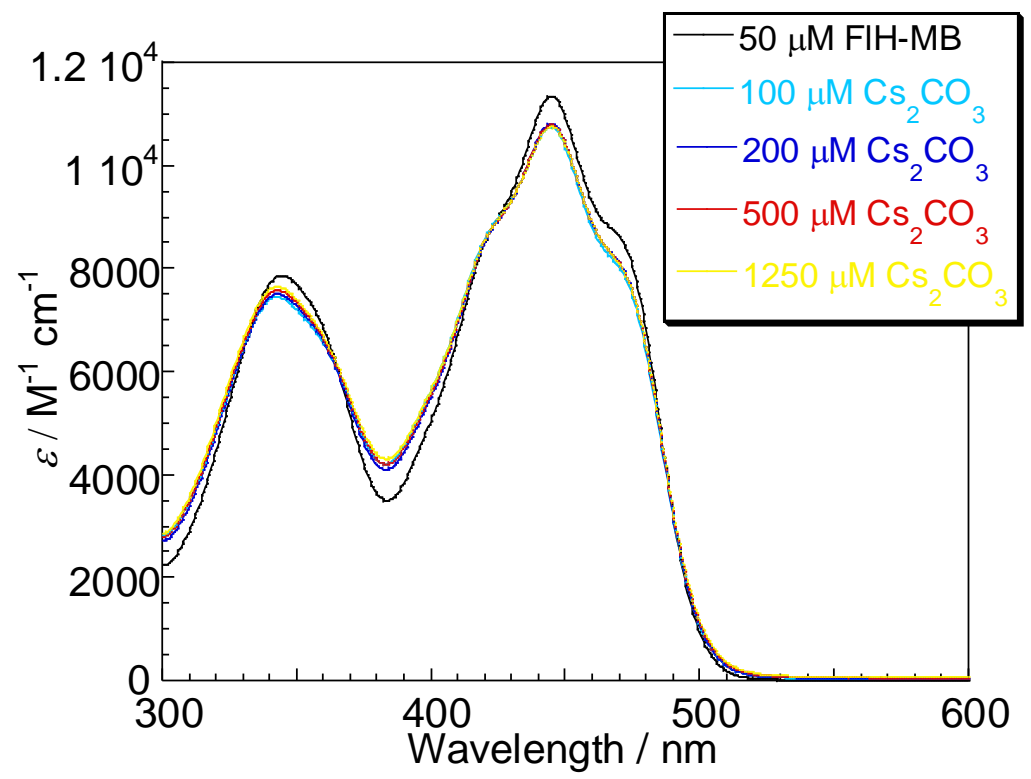

Figure S8. Absorption spectra of $\mathrm{FlH}-\mathrm{MB}\left(50 \mu \mathrm{M}\right.$, AcCN solution) titrated with $\mathrm{Cs}_{2} \mathrm{CO}_{3}$ aq. 


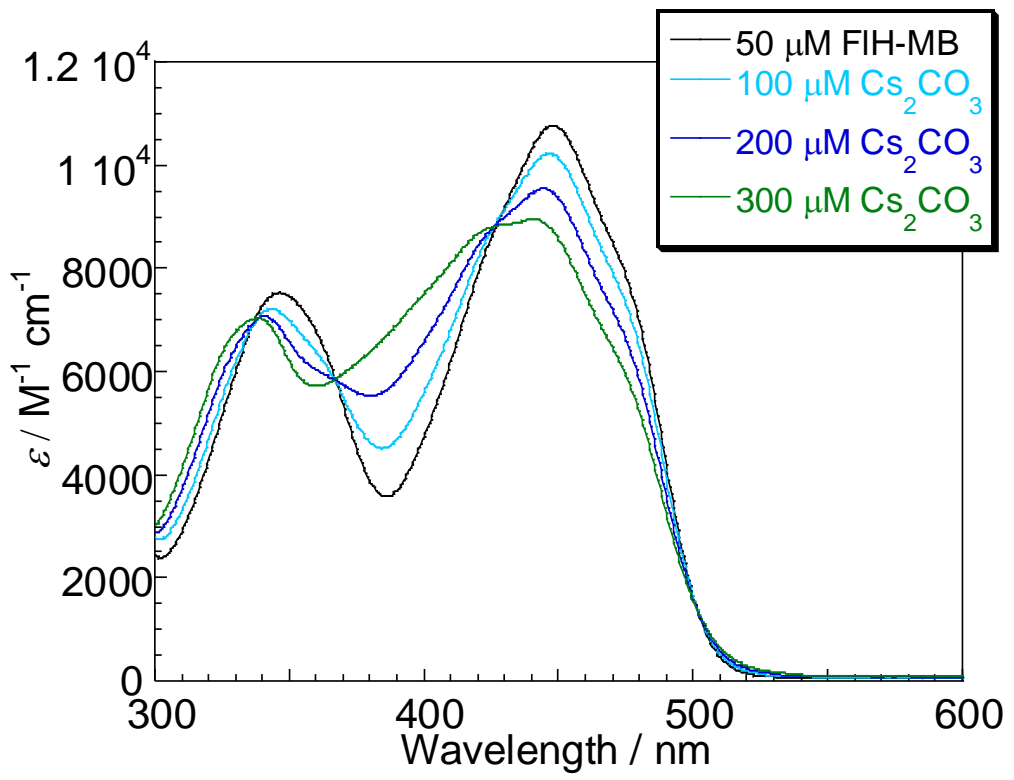

Figure S9. Absorption spectra of riboflavin ( $50 \mu \mathrm{M}$, DMSO solution) titrated with $\mathrm{Cs}_{2} \mathrm{CO}_{3}$ aq. 


\section{6. ${ }^{1} \mathrm{H}$ NMR titrations}

NMR titrations were performed at room temperature $\left(24^{\circ} \mathrm{C}\right)$ on a Bruker AV400 spectrometer (operating at $400 \mathrm{MHz}$ for ${ }^{1} \mathrm{H} \mathrm{NMR}$ ).

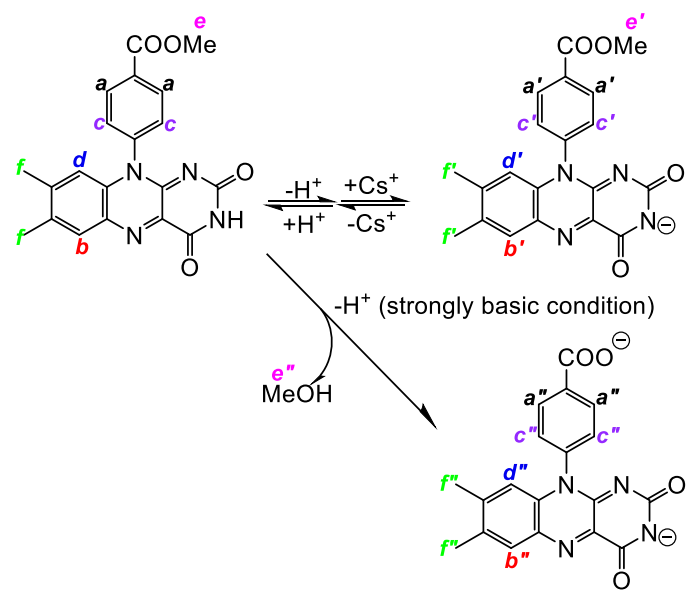

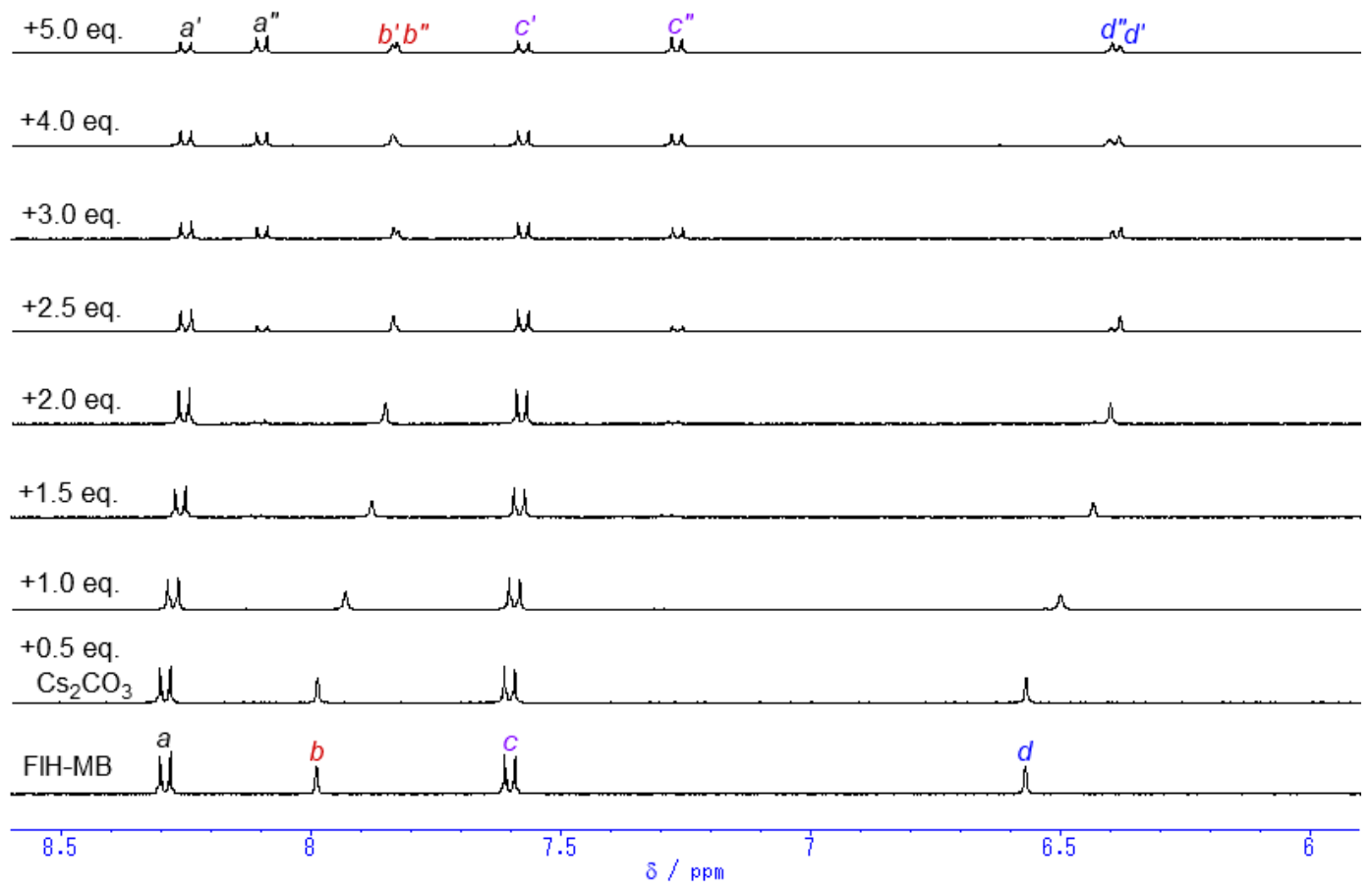




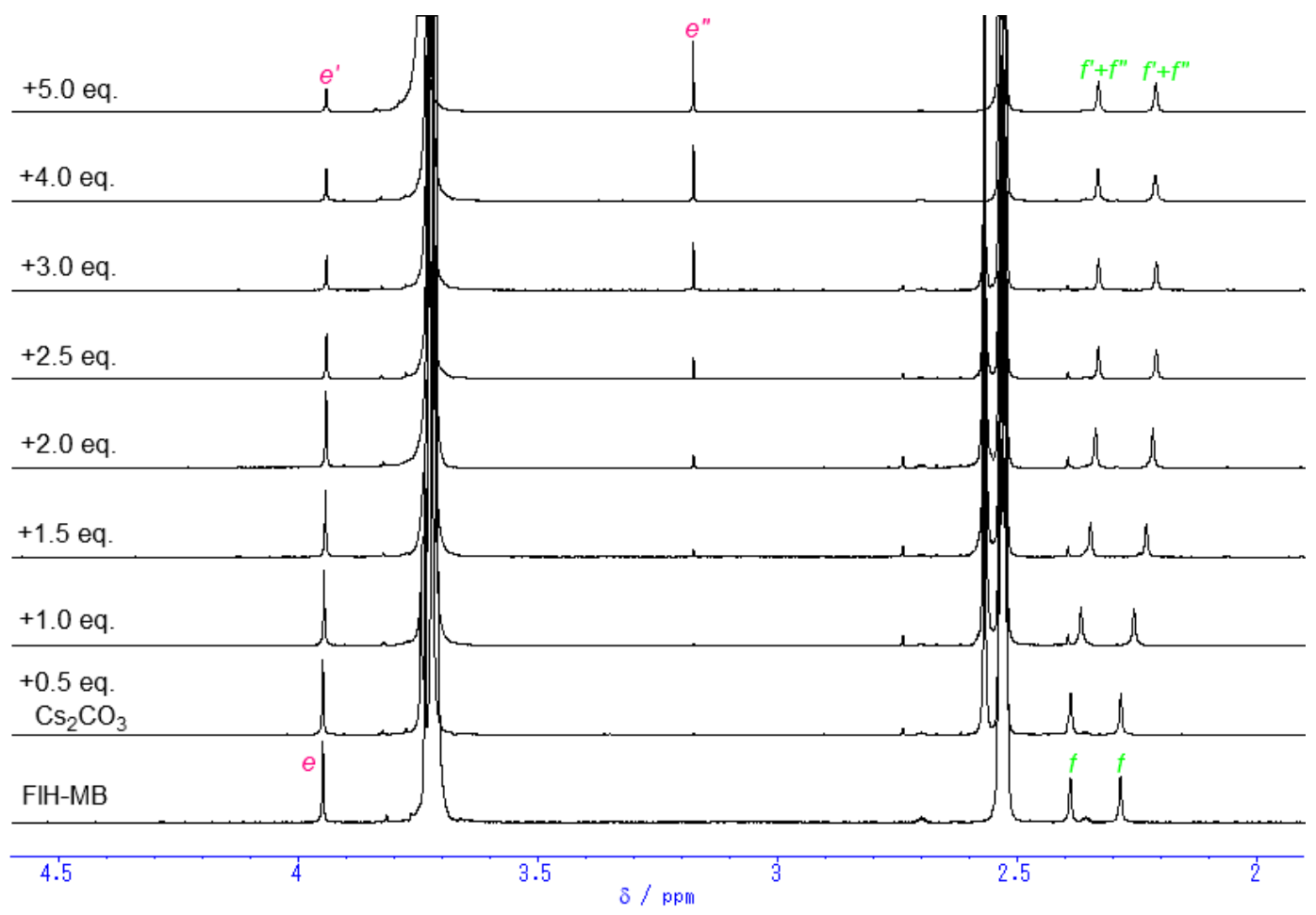

Figure S10. ${ }^{1} \mathrm{H}$ NMR spectra of FlH-MB (1.8 mM, DMSO- $\mathrm{d}_{6}: \mathrm{D}_{2} \mathrm{O}=9: 1$ solution) titrated with $\mathrm{Cs}_{2} \mathrm{CO}_{3}$ (0-5 molar equivalents), corresponding to Figure 3.

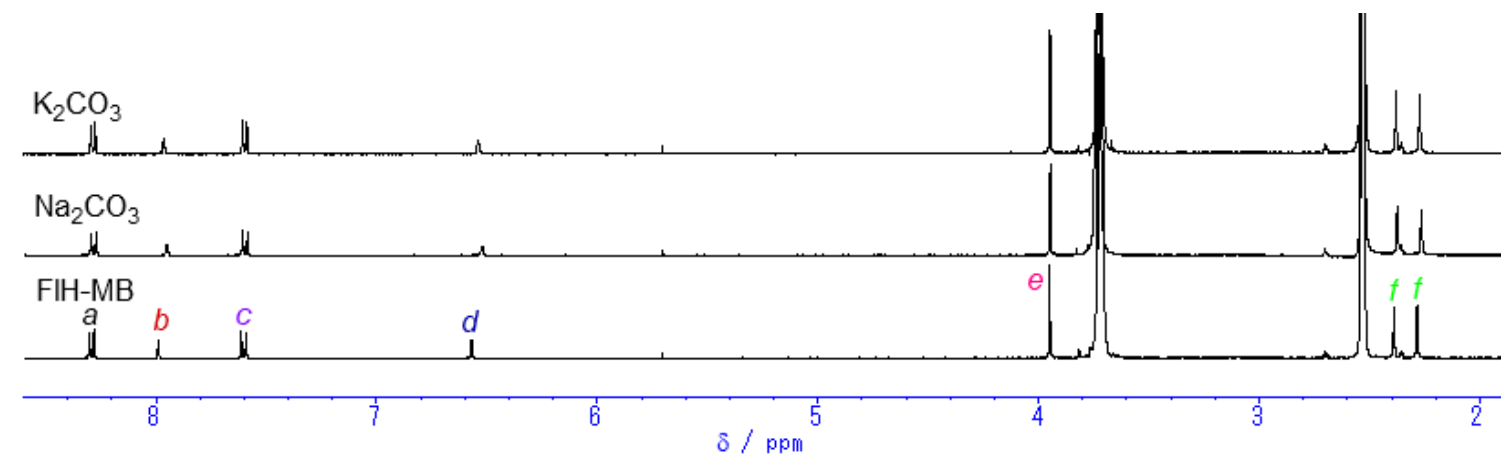

Figure S11. ${ }^{1} \mathrm{H}$ NMR spectra of FlH-MB $\left(1.8 \mathrm{mM}\right.$, DMSO- $\mathrm{d}_{6}: \mathrm{D}_{2} \mathrm{O}=9: 1$ solution $)$ titrated with $\mathrm{Na}_{2} \mathrm{CO}_{3}$ or $\mathrm{K}_{2} \mathrm{CO}_{3}$ (20 mM, saturated solution), corresponding to Figurer 3 (a). 


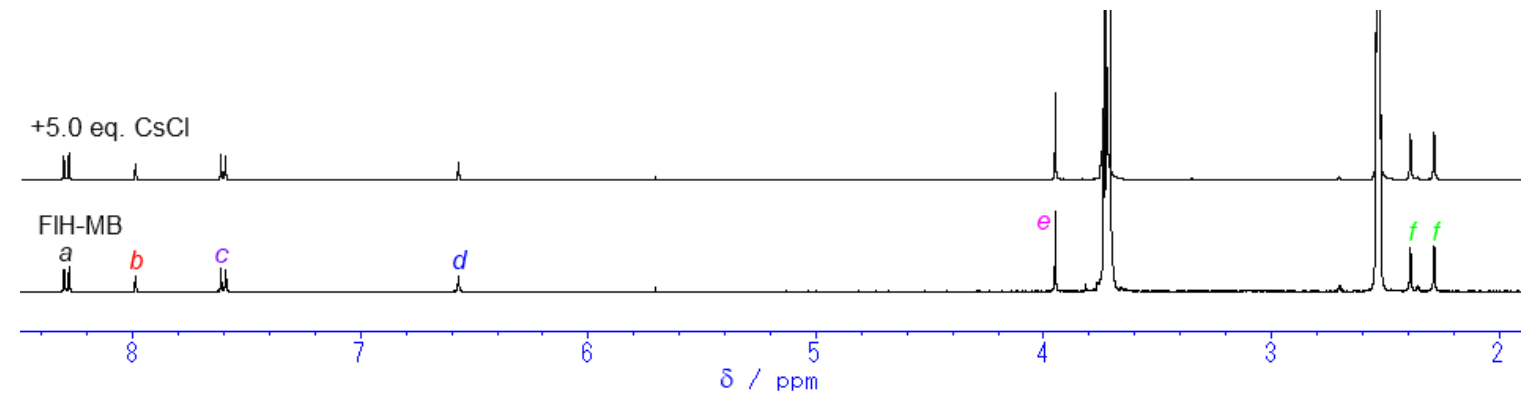

Figure S12. ${ }^{1} \mathrm{H}$ NMR spectrum of FlH-MB (1.8 mM, DMSO- $\mathrm{d}_{6}: \mathrm{D}_{2} \mathrm{O}=9: 1$ solution $)$ titrated with $\mathrm{CsCl}$ (5 molar equivalents).

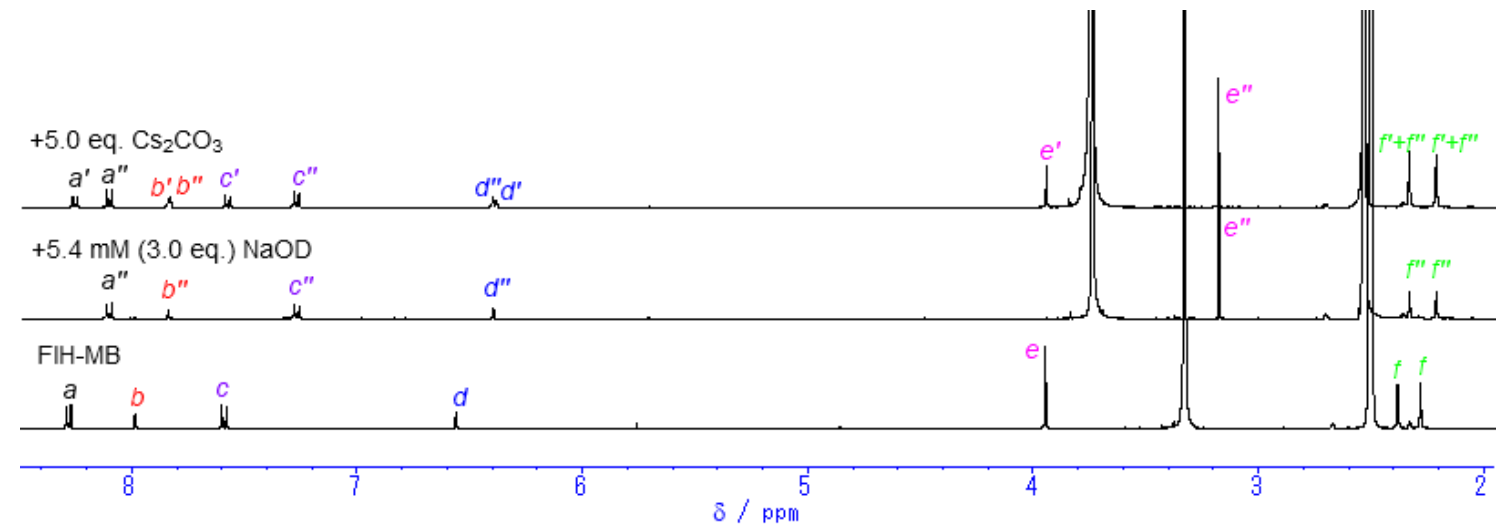

Figure S13. ${ }^{1} \mathrm{H}$ NMR spectrum of FlH-MB (1.8 mM, DMSO- $\mathrm{d}_{6}: \mathrm{D}_{2} \mathrm{O}=9: 1$ solution $)$ titrated with $\mathrm{NaOD}$ ( 3 molar equivalents, $5.4 \mathrm{mM}$ ). For comparison, the spectrum titrated with 5 molar equivalents of $\mathrm{Cs}_{2} \mathrm{CO}_{3}$, which is identical to Figure S10, is also shown. 
Table S4. Relative ratios of $\mathrm{Cs}_{2} \mathrm{CO}_{3}$-induced species.

\begin{tabular}{|c|c|c|c|}
\hline$\left[\mathrm{Cs}_{2} \mathrm{CO}_{3}\right]$ & $\mathrm{pH}$ & $\begin{array}{c}\text { ratio of } \\
\text { complex 1 }\end{array}$ & $\begin{array}{c}\text { ratio of } \\
\text { hydrolysis product }\end{array}$ \\
\hline 0 & 7 & 0 & 0 \\
\hline $0.9 \mathrm{mM}$ (0.5 eq.) & 10.64 & 0 & 0 \\
\hline $1.8 \mathrm{mM}$ (1.0 eq.) & 10.80 & $100 \%$ & 0 \\
\hline $2.7 \mathrm{mM}$ (1.5 eq.) & 10.88 & $95.5 \%$ & $4.5 \%$ \\
\hline $3.6 \mathrm{mM}$ (2.0 eq.) & 10.95 & $88 \%$ & $12 \%$ \\
\hline $4.5 \mathrm{mM}$ (2.5 eq.) & 10.99 & $81 \%$ & $19 \%$ \\
\hline $5.4 \mathrm{mM}$ (3.0 eq.) & 11.03 & $59 \%$ & $41 \%$ \\
\hline $7.2 \mathrm{mM}$ (4.0 eq.) & 11.10 & $55 \%$ & $59 \%$ \\
\hline $9.0 \mathrm{mM}$ (5.0 eq.) & 11.14 & $41 \%$ & $45 \%$ \\
\hline
\end{tabular}




\section{Determination of stability constants}

The stability constant of the complex can be estimated by ${ }^{1} \mathrm{H}$ NMR studies above the coalescence temperature by means of the Benesi-Hildebrand equation

$\frac{1}{\Delta}=\frac{1}{K_{c}} \frac{1}{\Delta_{0}} \frac{1}{a_{0}}+\frac{1}{\Delta_{0}}$

where $\Delta=$ observed shift of the ligand protons for the system in equilibrium relative to the shift for the pure ligand in solution, $\Delta_{0}=$ shift for the pure complex relative to the shift for the pure ligand in solution, $K_{\mathrm{c}}=$ equilibrium constant, and $a_{0}=$ metal concentration. ${ }^{7}$ The corrected $a_{0}$ was used due to the two competitive complexations in the presence of $\geq 1.5$ molar equivalents of $\mathrm{Cs}_{2} \mathrm{CO}_{3}$. From the relative ratios of two distinguishable complexes calculated by peak integrals, the effective concentrations of $a_{0}$ were calculated (as tabulated in Table S5), and $K$ values were evaluated graphically by plotting $1 / \Delta$ vs. $1 / a_{0}$ (Figure S14).

Table S5. Relative ratio of complex 1 and its effective $\mathrm{Cs}^{+}$ion concentration.

\begin{tabular}{|c|c|c|c|}
\hline$\left[\mathrm{Cs}_{2} \mathrm{CO}_{3}\right]$ & $\mathrm{pH}$ & $\begin{array}{c}\text { ratio of } \\
\text { complex 1 }\end{array}$ & $\begin{array}{c}\text { effective } a_{0} \\
\left(\left[\mathrm{Cs}^{+}\right]\right) \text {for } \\
\text { complex 1 }\end{array}$ \\
\hline 0 & 7 & 0 & 0 \\
\hline $0.9 \mathrm{mM}$ (0.5 eq.) & 10.64 & 0 & 0 \\
\hline $1.8 \mathrm{mM}$ (1.0 eq.) & 10.80 & $100 \%$ & $3.60 \mathrm{mM}$ \\
\hline $2.7 \mathrm{mM}$ (1.5 eq.) & 10.88 & $95.5 \%$ & $5.16 \mathrm{mM}$ \\
\hline $3.6 \mathrm{mM}$ (2.0 eq.) & 10.95 & $88 \%$ & $6.34 \mathrm{mM}$ \\
\hline $4.5 \mathrm{mM}$ (2.5 eq.) & 10.99 & $81 \%$ & $7.29 \mathrm{mM}$ \\
\hline $5.4 \mathrm{mM}$ (3.0 eq.) & 11.03 & $59 \%$ & $6.37 \mathrm{mM}$ \\
\hline $7.2 \mathrm{mM}$ (4.0 eq.) & 11.10 & $55 \%$ & $7.92 \mathrm{mM}$ \\
\hline $9.0 \mathrm{mM}$ (5.0 eq.) & 11.14 & $41 \%$ & $7.38 \mathrm{mM}$ \\
\hline
\end{tabular}




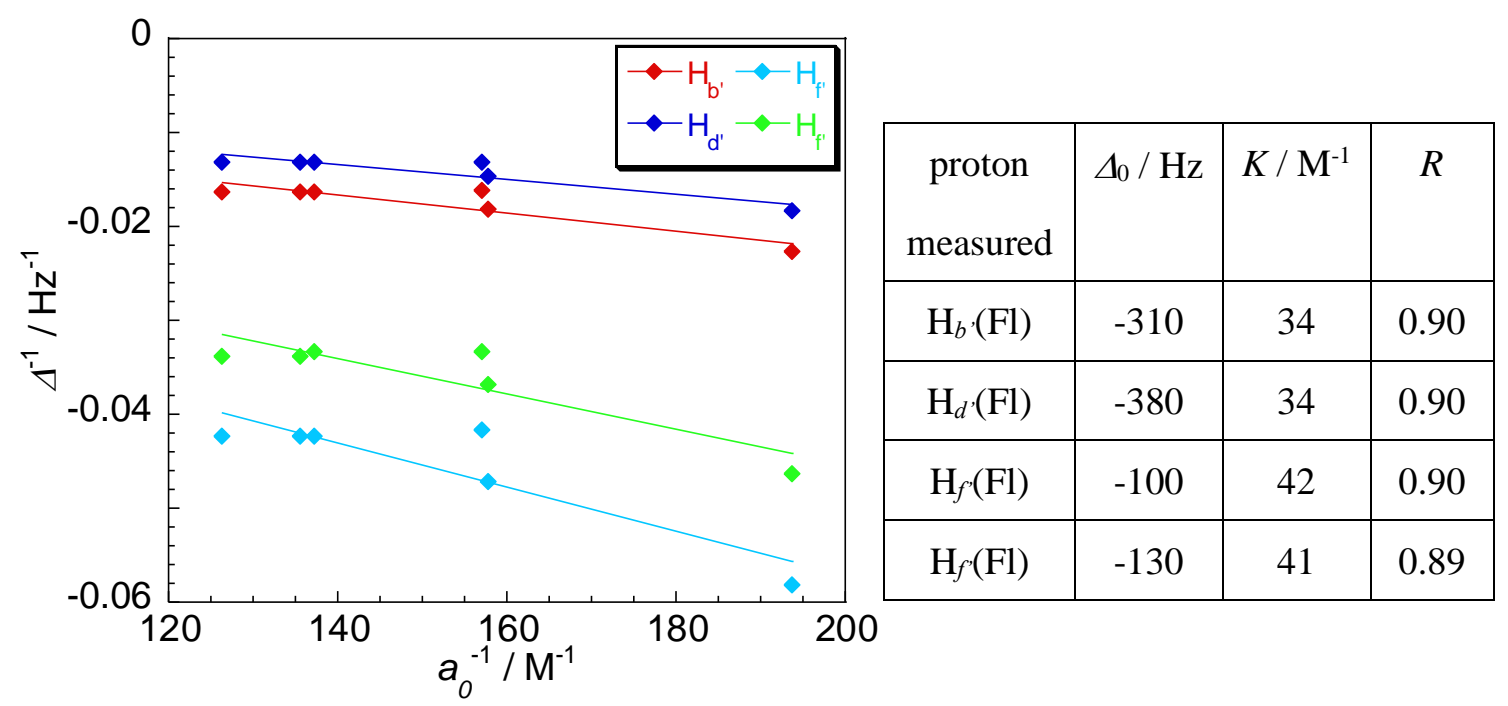

Figure S14. Plots of $1 / \Delta$ vs. $1 / a_{0}$ for complex 1 using the corrected $\mathrm{Cs}^{+}$ion concentration. 


\section{Fluorescence titrations}

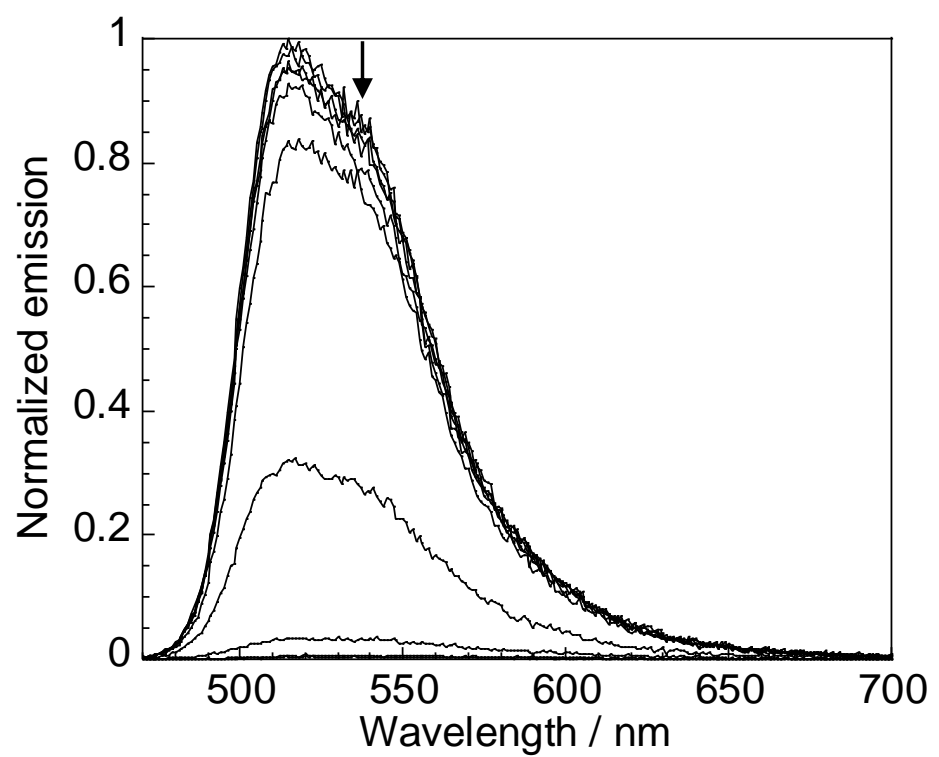

Figure S15. Fluorescence spectra of FlH-MB $\left(10 \mu \mathrm{M}\right.$, DMSO) titrated with $\mathrm{Cs}_{2} \mathrm{CO}_{3}$ aq. (0-200 $\mu \mathrm{M})$, corresponding to Figure 4. Excitation $450 \mathrm{~nm}$. 


\section{References}

(1) Sheldrick, G. M. A short history of SHELX. Acta Crystallogr. 2008, A64, 112-122.

(2) (a) Cromer, D. T.; Waber, J. T. "International Tables for X-ray Crystallography", Vol. IV, The Kynoch Press, Birmingham, England, Table 2.2 A, 1974. (b) Ibers, J. A.; Hamilton, W. C. Dispersion corrections and crystal structure refinements. Acta Crystallogr. 1964, 17, 781-782. (c) Creagh, D. C.; McAuley, W. J. "International Tables for Crystallography", Vol C, (A.J.C. Wilson, ed.), Kluwer Academic Publishers, Boston, Table 4.2.6.8, 1992. (d) Creagh, D. C.; Hubbell, J. H. "International Tables for Crystallography", Vol C, (A.J.C. Wilson, ed.), Kluwer Academic Publishers, Boston, Table 4.2.4.3, 1992.

(3) CrystalStructure 4.0: Crystal structure analysis package, Rigaku Corporation (2000-2010). Tokyo, Japan.

(4) Wang, M.; Fritchie, C. J. Geometry of the unperturbed flavin nucleus. The crystal structure of 10-methylisoalloxazine. Acta Crystallogr. 1973, B29, 2040-2045.

(5) Williams, A. T. R.; Winfield, S. A.; Miller, J. N. Relative fluorescence quantum yields using a computer-controlled luminescence spectrometer. Analyst 1983, 108, 1067-1071.

(6) Weigel, A.; Dobryakov, L.; Veiga, M.; Lustres, J. L. P. Photoinduced processes in riboflavin: superposition of $\pi \pi^{*}-\mathrm{n} \pi^{*}$ states by vibronic coupling, transfer of vibrational coherence, and population dynamics under solvent control. J. Phys. Chem. A 2008, 112, 12054-12065.

(7) Pierre, J.-L.; Baret, P.; Chautemps, P.; Armand, M. [2.2.2]paracyclophane, a novel type of metal cation complexing agent ( $\pi$-prismand). J. Am. Chem. Soc. 1981, 103, 2986-2988. 